\title{
A Conceptual Model of Business Intelligence System Adoption for the Textile and Apparel Industry in Pakistan
}

\author{
Sumera Ahmad', Suraya Miskon² \\ RECEIVED ON 19.04.2020, ACCEPTED ON 16.12.2020
}

\begin{abstract}
Textile and Apparel (T\&A) industry is the backbone of Pakistani economy, including one-fourth of the industrial sector, and comprises $40 \%$ of industrial employees and approximately $60 \%$ share of Pakistani exports. Although, industry is striving hard to compete in international market; a persistent stream of innovation is required to maintain its due share in recent quota free global trade of textiles. Business Intelligence (BI) system is one of the most-used buzzwords in the modern business landscape for well informed decision making. In spite of the great synergies and benefits, BI system grant to the businesses and organizations. The adoption level is low with high failure ratio, especially in developing countries. Further, researchers did not propose any theory or model for the $T \& A$ industry. This study aims to fill this gap by conducting a Systematic Literature Review (SLR) for identifying the most appropriate factors, theory and model for the current study. Total of 75 studies were selected which were published during the period of 20112020. A conceptual model is developed with most potential factors by using Technology-OrganizationEnvironment (TOE) framework. This conceptual model will guide the policy makers and industry practitioners to integrate and adopt the BI system successfully that would helpful to achieve competitive edge in the international business markets.
\end{abstract}

Keywords: Textile \& Apparel industry; Industry issues, Business intelligence systems adoption, Theories, Factors.

\section{INTRODUCTION}

T The Textile and Apparel (T\&A) industry of Pakistan is considered as one of the oldest industries with great significance in terms of investment, revenues, employment, and trade in the world [1]. The industry has an ample experience and tradition since the $19^{\text {th }}$ century as well as good repute around the world. It is playing a very important role in Pakistani economy. Hence, Pakistan has a complete textile value chain as compared to its competitors which only have finished or primary base of textile industry. Complete value chain of the textile industry like Pakistan is rare in the world [2]. Pakistani T\&A industry is categorized into four main sectors: textile manufacturing, apparel production, marketing/customer services and sales/ distribution [3]. The first sector of the textile industry is manufacturing that consists of some operational procedures such as the conversion of raw material into finished textile products like 'fiber-to-yarn', 'yarn-tofabric', then dying and printing. Apparel production is another sector of industry in which textile products convert into finished garments according to the required designs and customers' demands. The operational procedures of apparel production are material management, product design, product development, tailoring, finishing and packing.

${ }^{1}$ School of Computing, Faculty of Engineering, Universiti Teknologi Malaysia, Johor Bahru, 81310, Johor, Malaysia. Email: ahmad.sumera@graduate.utm.my (Corresponding Author)

2 Department of Information Systems, Azman Hashim International Business School, Universiti Teknologi Malaysia, Johor Bahru, 81310 Johor Malaysia.Email: suraya@utm.my

This is an open access article published by Mehran University of Engineering and Technology, Jamshoro under CC BY 4.0 International License. 
Marketing/customer services fall into the third sector; the operational processes of this sector refer to the campaign management, promotions, business deals, sales methodologies for managing customer relationships etc. The last sector of the T\&A industry is sales/distributions, which involves the wholesaling, retailing and product delivery. The main characteristics of this industry are a shorter product life cycle and unexpected customer demands. The fast fashion and seasonal nature of T\&A products are other prominent issues of this industry. Further, the fashion market can be observed as one of the ficklest and unpredictable markets [4]. Along these determinants, Pakistani T\&A industry is not only expanding and growing positively but also facing the intensive competitive pressure due to their regional players which are China, Vietnam, Bangladesh and India. These challenges are; increasing market share, entering new markets, improving supply chains, reducing energy and material costs per unit, and improving the quality of goods. Therefore, now timeto-market is a significant determinant for the T\&A industry of Pakistan to remain in dynamic markets. Hence, for a log period, a time-based competition has been a strategic policy direction for this industry but still lagging to secure its due share in the international market. In addition, rapid growth of smart organizations put pressure on industry [5]. To cope with these challenges, industry is prone to adopt modern systems and technologies to offer best incentives to the customers with a view to achieve market leadership [3]. As a result modern systems and technologies produce a large amount of data, which reveals, there is more competition in contemporary's trade patterns [6]. To preserve the competitiveness of industries, business decisions must necessarily be supported by high quality and prompt information about events within and outside the industry [7]. Industry needs trusted information systems that provide adequate access to quality information that is necessary to make timely and effective business decisions [8]. One technology or innovation that can be helpful to meet the business goals with well-informed decision-making is Business Intelligence (BI) system [9]. It empowers the firms to escalate its productivity, deliver excellent customer service by improving the operational efficiency, and help to diminish the risks related to business $[10,11]$. It is endorsed by researchers and practitioners that BI technologies have attained remarkable consideration from both organizations and industry $[12,13]$ due to its extant benefits. BI system revolutionized the business operations in the worldwide economies that range from $73 \%$ to $97 \%$ in Europe and $87 \%$ at international level [12]. It has been shown by research with the sample of 287 firms in 18 countries all over the world, that BI system has been adopted by $97 \%$ organizations in Switzerland, 96\% in Germany, 95\% in Finland, 89\% in Asian territory, Mexico, and Brazil, $79 \%$ in Canada, $76 \%$ in the Netherlands, $73 \%$ in Norway, and $87 \%$ of firms have adopted BI systems at international level [10]. Researchers have categorized the BI systems into three major types: operational, strategic and tactical (see Table 1). It is significant for policy makers, owners/ managers to attain a comprehensive view of the types of BI systems before adoption and implementation. This information shall be helpful for companies in selecting the most appropriate BI system according to their requirements.

\begin{tabular}{|l|l|}
\hline \multicolumn{1}{|c|}{ Table 1: Types of BI systems } \\
\hline \multicolumn{1}{|c|}{ Types } & \multicolumn{1}{c|}{ Description } \\
strategic BI & $\begin{array}{l}\text { supports for strategic goals like, traditional } \\
\text { decision support, monitoring business } \\
\text { activity, customer relation optimization, } \\
\text { business transformation and corporate } \\
\text { performance [14]. }\end{array}$ \\
\hline $\begin{array}{l}\text { Operational } \\
\text { BI systems }\end{array}$ & $\begin{array}{l}\text { improves service and production processes, } \\
\text { cutting operational costs and optimizing } \\
\text { marketing, retailing and supply-chain } \\
\text { management activities [15]. }\end{array}$ \\
\hline $\begin{array}{l}\text { Tactical BI } \\
\text { systems }\end{array}$ & $\begin{array}{l}\text { supports business experts and analysts for } \\
\text { everyday routine jobs including accessing and } \\
\text { analyzing data for several short-term business } \\
\text { decisions making [16]. }\end{array}$ \\
\hline
\end{tabular}

There are some key challenges of the T\&A industry of Pakistan:

- A quick response is required to rapid fashion changes whose first priority is to meet the customer's requirements for anything unique and modern.

- International quota free system for textile products put pressure on Pakistani T\&A industry to compete harder for its due share in global trade.

- The competitive pressure demands the innovation adoption, new marketing strategies, and advanced 
organizational structures to maintain its sustainability in the global economy [17].

- In the era of industry 4.0, industry is prone to adopt modern systems and technologies such as cloud technology, big data, mobile technology, Internet of Things (IoT), and Radio Frequency Identification (RFID) [18]. As a result, modern systems and technologies produce a large amount of data.

- Industry needs trusted information systems to process large datasets that provide quality information to managers and business analysts as well as officials of all levels for timely and effective business decisions making [19].

BI systems have some especial prominent characteristics that attracted the policy makers to integrate this incredible innovation in contemporary businesses to resolve the business challenges [20]. Following are some key characteristics of BI systems.

- $\quad$ BI systems make analytical processes easy about market positions, capabilities, operations and goals of a company by transforming the large data sets into knowledgeable information that leads the enterprises in order to stay competitive $[21,22]$.

- The most frequently utilization of BI analytical techniques reflected the value of BI system, (1) forecasting of strategic business processes development, (2) credit scoring (3) web and text mining, (4) logistics optimizations (5) analysis of customer loyalty, (6) up selling and cross selling analysis, (7) profiling and customer segmentation, (8) fraud detection, (9) survival time analysis and parameters importance analysis etc. [23].

BI system is used in multiple departments of industry (sale, marketing, retailing, finance etc.) to support effective marketing campaigns, to monitor the behaviors of customers and to analyze profitability of different products and sectors [24]. Therefore the above-mentioned characteristics of BI system enable the T\&A industry to overcome international trade challenges by detecting business threats and opportunities with real time decision-making [25]. The widespread adoption of BI systems is a complex task that necessitates exploring by novel research dimensions. According to the researchers, the term adoption means the resolution of individual users to make full use of a technology as though that is the only option available. A technology is considered successfully adopted when users leverage its value with proper implementation. In a large number of published studies, the practitioners and scholars are still discussing the tactical, management and strategic approaches to the successful integration and adoption of BI systems. However, the existing body of knowledge is not sufficient in this perspective due to limited available studies. For example, Hatta at el. [26] conducted the BI review study from 2009 to 2015. They discussed the potential theories for BI adoption in SME and Ain et al. [27] reviewed the two decades (2000-2019) of research on BI adoption, utilization and success. Thus, to the best of our knowledge, no study is available that explored the significant factors for the adoption of BI systems. In addition, the nonexistence of BI system adoption model for the T\&A industry, especially for Pakistani T\&A industry leads to conduct of this study. Overall researchers have neglected this important industry in the perspective of $\mathrm{BI}$ adoption $[4,20]$. Thus, the objective of this study is to fill this gap by conducting Systematic Literature Review (SLR) of BI systems adoption studies from 2011 to 2020. Based on SLR, the following objectives are designed to address the research problem:

1- To explore the factors and theories from the selected studies related to the adoption of $\mathrm{BI}$ system.

2- To identify the most significant factors.

3- To categorize the significant determinants into technological, organizational and environmental perspectives for developing a conceptual model of BI system adoption for the T\&A industry of Pakistan.

The rest of the paper is structured as follows: the methodology for conducting SLR is presented in Section 2. Section 3 consists of results and discussion. Further, section 4 comprises the theoretical foundation of this study that developed the conceptual model for BI system adoption. The last Section 5 presents not only the implications and conclusion but also discusses the study limitation and future research 
directions.

\section{METHODOLOGY}

This study selected eight online databases for downloading research papers in the extant literature that are applicable to this study. Eight prominent online databases are Academic Search Premier Science Direct, Emerald Full text, ABI/INFORM, google scholar, IEEE/IEE Electronic Library, Elsevier, MDPI, Springer and Taylor \& Francis online. Articles were searched by utilizing the keywords textile, apparel industry, industry issues, Business Intelligence system adoption, theories, factors and decision making. Three phase technique is adopted to extract, analyze and report the findings [28]. Inclusion search criteria was employed that included: (1) textile and apparel industry (2) behavioral studies that comprised conceptual models, theories and preposition related to BI system, (3) studies that observed BI systems adoption with factors using any theory or framework. The exclusion criteria consisted of: (1) studies not related to textile and apparel industry, (2) all technical studies, (3) studies of BI systems adoption in other languages except English language. As the review study is a part of Information Technology (IT)/Information System research area that is changing rapidly. Therefore, the time span of this study is decided from 2011 to 2020. Those studies were also excluded that were published before 2011. By looking at the title, and keywords a total of 406 articles were selected. 14 duplicate studies were removed after $1^{\text {st }}$ scanning. Moreover, 248 studies were discarded after reading the abstract. Further 69 papers were removed as they were not relevant to the scope of the paper. Only 75 studies are included which qualify for this SLR according to the inclusion criteria. SLR is summarized in a flow diagram (see Fig. 1).

\section{RESULTS AND DISCUSSION}

Total of 75 articles were selected for the current study which addressed the different perspectives of the study objectives such as textile and apparel industry, industry' s key challenges, BI system adoption applied theories, models and factors. Studies were reviewed individually in detail to address the key requirements of this study for developing a conceptual BI systems adoption MODEL for the T\&A industry of Pakistan.

\subsection{General Findings}

\subsubsection{Publication Source Overview}

Most articles were identified from well-established platforms such as high-quality journals and leading conferences indexed by Web of Science and Scopus. Initially, studies were identified to provide accurate high-quality information on BI system adoption phenomenon. The main source of 68 identified publications was high quality journals, 1 conference, 1 industry report and followed by 3 book chapters as depicted in Table 2.

\begin{tabular}{|l|l|c|}
\hline \multicolumn{3}{|c|}{ Table 2: Publication types. } \\
\hline S. No & \multicolumn{1}{|c|}{ Publication type } & Frequency \\
\hline 1 & Journal articles & 68 \\
\hline 2 & Conferences & 1 \\
\hline 3 & Book chapter & 3 \\
\hline 4 & Industry report & 1 \\
\hline
\end{tabular}

\subsubsection{Research Methods}

Researchers applied different research methods for the BIS systems research such as quantitative, qualitative, mixed methods and literature reviews etc. The analysis of the current study shows that researchers have adopted quantitative methods more frequently by conducting surveys with questionnaires. The second most identified research approach was qualitative with 22 studies based on case studies and Delphi studies in which researchers investigate the phenomenon of interest with interviews, documentation, observations and focused group discussions. Further, 10 studies were identified as literature reviews and only 2 studies used mixed methods approach. The selected studies were categorized according to the research methodologies as shown in Table 3, where Fr denotes frequency.

\subsubsection{Year-wise Distribution of Articles}

As mentioned by a researcher in [29] that published literature on BI system as a separate entity is limited. 
Thus, Fig. 2 presents the year-wise distribution of all selected articles from 2011 to 2020 . We noticed that researchers have paid less attention to this research area in 2011 and 2013 with 4 and 3 studies only among the 75 articles. Whereas, published studies were increased little bit in 2015, 2017 and 2019 with the same number of 8 articles as per year. However, high rise of published literature can be observed in 2016 with 10 and in 2018 with 11 articles. On the other hand, 2012 and 2020 were noticed with the same number of published studies that is 7 and 2014 stands alone with 9 published studies as depicted in Fig. 2.

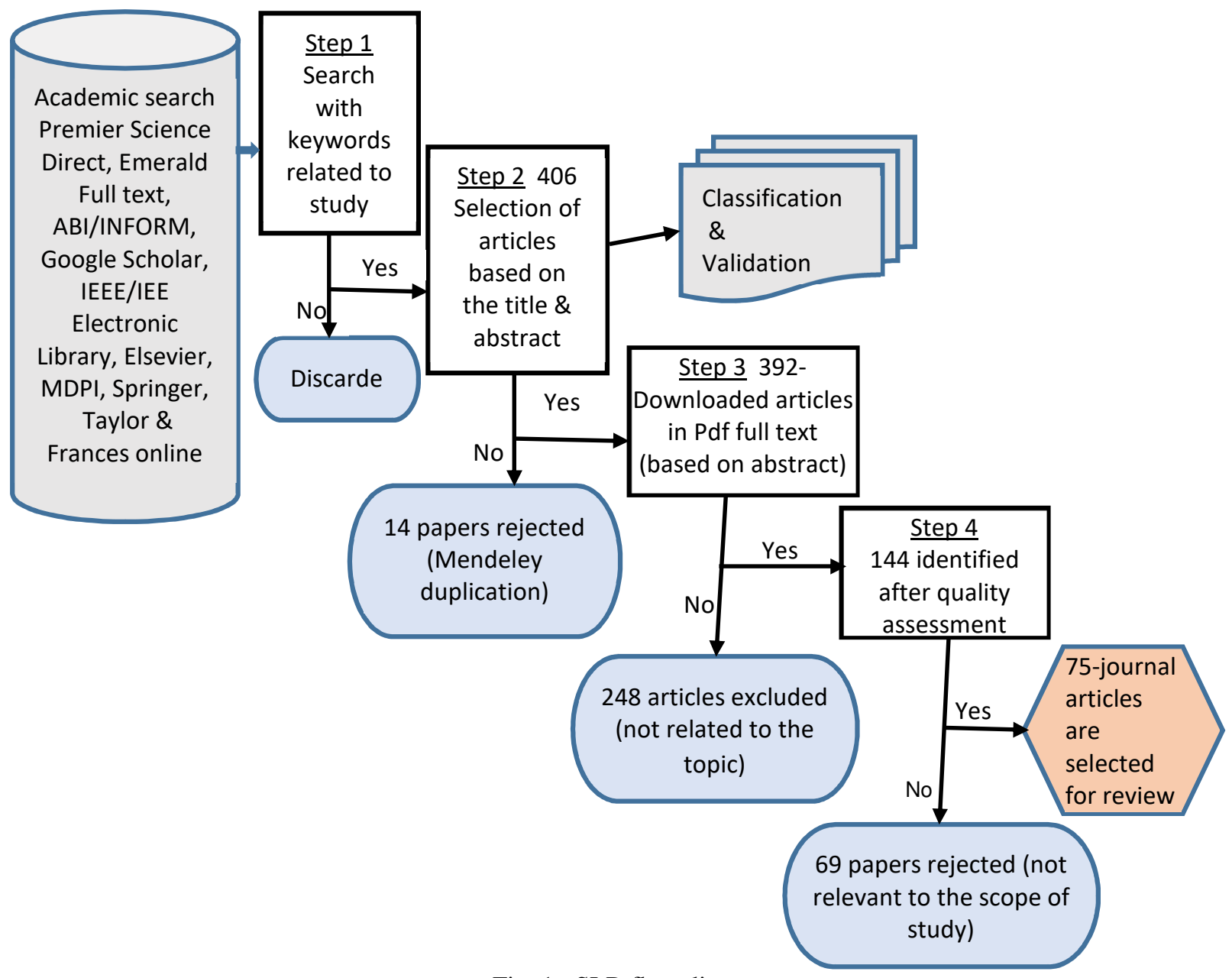

Fig. 1: SLR flow diagram

\begin{tabular}{|c|l|l|c|}
\hline \multicolumn{3}{|c|}{ Table 3: Research Methods. } \\
\hline S. No & \multicolumn{2}{|c|}{ Research Methods } & Fr \\
\hline 1 & Quantitative (Survey with questionnaires) & 39 \\
\hline 2 & Qualitative & $\begin{array}{l}\text { Case studies (interviews, } \\
\text { documents, and } \\
\text { observations). }\end{array}$ & 22 \\
& $\begin{array}{l}\text { Delphi studies (focused } \\
\text { group interviews and } \\
\text { discussion) }\end{array}$ & \\
\hline 3 & $\begin{array}{l}\text { Literature Reviews (Bibliometric and } \\
\text { systematic literature review) }\end{array}$ & 10 \\
\hline 5 & Mixed methods (Quantitative +Qualitative) & 2 \\
\hline
\end{tabular}

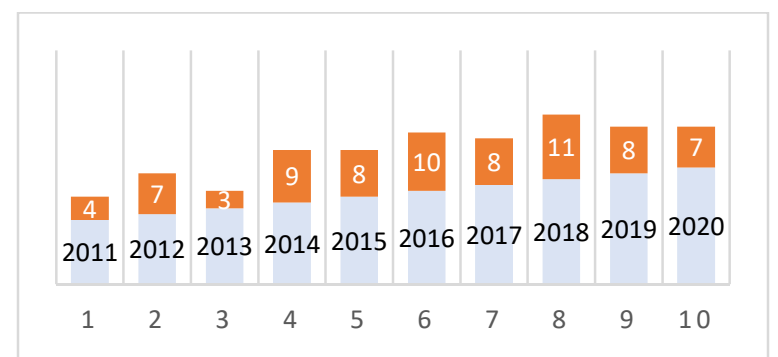

Fig. 2: Year-wise distribution of articles from 2011 to 2020. 


\subsubsection{Sector-wise Distribution of Articles}

After the analysis of the study results, multiple sectors were recognized for the BIS research such as SME, banks, logistic services company, academic, health care sector, manufacturing industries, insurance, telecommunication industry and some behavioral studies. The detailed distribution of studies is revealed by Fig. 3 .

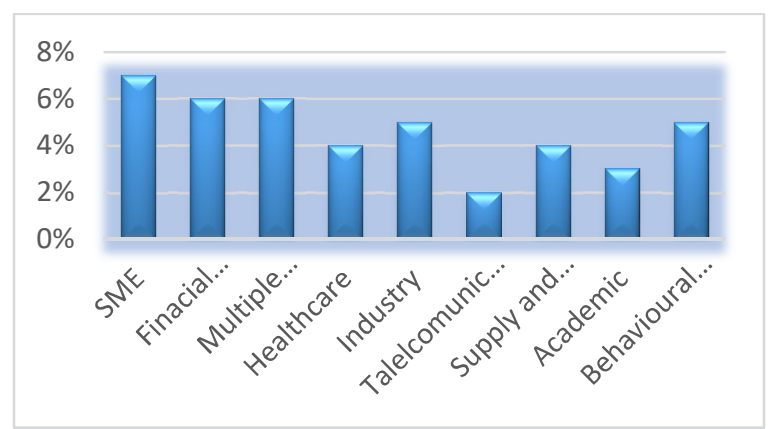

Fig. 3: Sector-wise distribution of articles

\subsubsection{Geographical Distribution of Studies}

Geographical distribution of selected studies has been analyzed for this SLR according to the current study objectives. It is revealed by Table 4 that researchers focused more in developed countries in the perspective of BI system adoption rather than developing countries. Total 47 studies were identified with theories and factors used for the adoption of BI systems. Remaining 28 studies were relevant to the research background and discussions. Table 4 is revealing the distribution of the studies related to the core topic of the current study.

\subsection{Key Findings Addressing the Research Objectives}

\subsubsection{Models/Frameworks and theories used for BI system research}

The selected models are limited in numbers because most researchers have just focused on the components of BI systems, in terms of adoption and implementation such as data mining and OLAP etc. Thus, studies which investigated the BI system adoption as a separate entity is scarce [29]. It is depicted by Table 5 and Table 6 that most researchers preferred to use the Technology-OrganizationEnvironment (TOE) framework and Technology Acceptance Model (TAM) for BI system adoption. It is also observed that most researchers preferred to use the Diffusion Of Innovation (DOI) theory for technological perspective and Institutional Theory for environmental perspective. On the other hand, Unified Theory of Acceptance and Use of Technology (UTAUT) and Theory of Planned Behaviour (TPB) have been used for investigating behavioral perspectives. Resource-Based View (RBV) Theory was used for assessment of organizational resources.

\subsubsection{Significant Factors Identification}

The most frequent utilized factors are presented in Table-7 that influenced the adoption of BI systems.

\begin{tabular}{|c|c|c|c|c|c|c|c|}
\hline \multicolumn{7}{|c|}{ Table 4: Geographical Distribution of Studies } \\
\hline $\begin{array}{c}\text { S. } \\
\text { No }\end{array}$ & Country & Authors & Fr & S. No & Country & Authors & Fr \\
\hline 1 & Malaysia & {$[7,16,30-33]$} & 6 & 10 & Poland & {$[34,35]$} & 2 \\
\hline 2 & Slovenia & {$[13,36-40]$} & 4 & 11 & South Africa & {$[41-46]$} & 5 \\
\hline 3 & Croatian & {$[10,47]$} & 2 & 12 & Australia & {$[13,15]$} & 2 \\
\hline 4 & Portugal & {$[48]$} & 1 & 13 & USA & {$[8,49-52]$} & 5 \\
\hline 5 & Thailand & {$[53,54]$} & 2 & 14 & Canada & {$[55]$} & 1 \\
\hline 6 & Iran & {$[56-58]$} & 3 & 15 & Taiwan & {$[59-61]$} & 3 \\
\hline 7 & Multiple & {$[5,9,12,20,62]$} & 5 & 16 & Spain & {$[63]$} & 1 \\
\hline 8 & India & {$[64]$} & 1 & 17 & UK & {$[65]$} & 1 \\
\hline 9 & Brazil & & 1 & 18 & Colombia & {$[11,66]$} & 2 \\
\hline
\end{tabular}

Table 5: Frameworks/ Models used for BI system research

\begin{tabular}{|c|c|}
\hline \multicolumn{2}{|c|}{ Table 5: Frameworks/ Models used for BI system research } \\
\hline Models/Frameworks & Authors \\
\hline Technology-Organization-Environment (TOE) & {$[9,38,41,43,44,46,47,52-54,56,57,63]$} \\
\hline Technology Acceptance Model (TAM) & {$[29,45,60,62,67,68]$} \\
\hline
\end{tabular}




\begin{tabular}{|l|c|}
\hline \multicolumn{2}{|c|}{ Table 6: Theories used for BI system research } \\
\hline \multicolumn{1}{|c|}{ Theories } & Authors \\
\hline Diffusion of Innovation (DOI) & {$[7,9,16,37,38,40,43,44,46,48,52-54,56,62]$} \\
\hline $\begin{array}{l}\text { Unified Theory of Acceptance and Use of } \\
\text { Technology (UTAUT) }\end{array}$ & {$[37,39,45,61]$} \\
\hline Institutional Theory & {$[38,43,44,46,51-54,56]$} \\
\hline Resource-Based View (RBV) Theory & {$[23,48,69]$} \\
\hline Theory of Planned Behavior (TPB) & {$[23,36,39,60]$} \\
\hline
\end{tabular}

These factors are extracted from the reviewed studies which were utilized for the BI systems adoption. It is impossible to present all identified factors in the current study due to large numbers. Therefore, only a few factors were presented based on their frequency of use in literature. The relative advantage is topped in the list with usage frequency of 13 , followed by complexity, compatibility and organization size with the frequency of 11. Further, competitive pressure and Organizational readiness are identified with the frequency of 9 , whereas cost and top management factors ranked with frequency of 8 . In addition, observability, information quality, social influence, perceived usefulness, perceived ease of use factors were ranked middle with frequency of 7,6 and 5 respectively. Few factors were observed with frequency of 4,3 and 2 such as regulatory body, trialability, presence of champion, behavioural beliefs, organizational resources, Institutional isomorphism, market trends, and vendor support. Although, factors frequency has been counted because of their persistent utilization with same name without any specific judgment but similar terms have been utilized differently by some researchers such as relative advantage and perceived tangible and intangible benefits. However, some factors revealed the same meaning of other factors such as perceived benefits and relative advantage. Therefore, all factors with the same meanings were considered one. The frequent repetition of various factors can be observed that showed the adoption behavior of BI systems. However, previous studies revealed that researchers emphasized more on technological factors for innovation adoption [56] but the results of current study contradict this perception by revealing that organizational factors have more impact as compared to other two such as technological and environmental factors. It is found by prior researchers that behavioral factors influenced the least for the BI system adoption. A limited number of studies validated and addressed the significance of the Behavioral perspective. The most potential factors with their frequencies and perspective are shown in Table 7 that were selected from those studies which were conducted to investigate the BI systems research perspectives.

\section{MODEL DEVELOPMENT}

Researchers give great importance to the development or refinement of any theory or model. Despite its potential significance within information discipline, the development of new theory or conceptual models have been neglected by the scholars [70, 71]. It is revealed by rigorous systematic literature review, a limited number of studies have been found with models and theories for the adoption of BI systems. A good quality conceptual model and theory have great significance to add the knowledge of practitioners and researchers within the theoretical domain $[28,72]$.

Weber stated in [70], that a theory or model development might make novel contributions to a discipline, in the current scenario is BI system adoption model. As it is indicated by the study findings the non-existence of any theory or model with precise prediction related to the BI system adoption in any sector of Pakistan is found out. Further, the research on the adoption of BI systems in the T\&A industry is scarce across the world [5, 20, 74, 75]. Therefore, this study is conducted with the intention to propose a conceptual model for the BI system adoption in the T \& A industry of Pakistan. As a result, the detailed analysis of the models and theories has been done for selection of the most appropriate theory, model and factors. It is clear by prior studies that innovation adoption decisions are greatly influenced by considering the most significant determinants [26, 63]. Hence it is not possible to include all extracted potential factors that influence the adoption of BIS in the current study. Based on the SLR, multidimensional 


\begin{tabular}{|c|c|c|}
\hline \multicolumn{3}{|c|}{$\begin{array}{c}\text { Table 7: Most frequently utilized factors for the } \\
\text { adoption of BI systems. }\end{array}$} \\
\hline Factors & Frequency & Perspective \\
\hline Relative advantage & 13 & Technological \\
\hline Complexity & 11 & Technological \\
\hline Compatibility & 11 & Technological \\
\hline Organization size & 11 & Organizational \\
\hline Competitive pressure & 9 & Environmental \\
\hline Organizational readiness & 9 & Organizational \\
\hline Cost & 8 & Organizational \\
\hline Top management support & 8 & Organizational \\
\hline Observability & 7 & Technological \\
\hline Information quality & 6 & Organizational \\
\hline Social influence & 5 & Environmental \\
\hline Perceived usefulness & 5 & Behavioral \\
\hline Perceived ease of use & 5 & Behavioral \\
\hline Regulatory body/ compliance & 4 & Environmental \\
\hline Trialability & 4 & Technological \\
\hline Presence of Champion & 4 & Organizational \\
\hline Behavioral beliefs & 4 & Behavioral \\
\hline Organizational resources & 3 & Organizational \\
\hline Institutional isomorphism & 3 & Environmental \\
\hline Organizational data & 2 & Organizational \\
Environment & & \\
\hline Requisite knowledge \& skills & 2 & Organizational \\
\hline Facilitating conditions & 2 & Organizational \\
\hline Market trends & 2 & Environmental \\
\hline Vendor support & 2 & Environmental \\
\hline
\end{tabular}

are popular for innovation adoption in organizations where many research scholars adopted the TOE model for technology adoption at organizational level. The TOE framework was considered the best choice for this study because of its flexibility. The TOE model can be deployed to identify a bunch of attributes that may be significant in the diffusion of innovation at organizational level. Despite this, the TOE framework does not provide a tactile model describing the determinants that affect the organizational decisions to adopt any innovation, but it is flexible to integrate multiple dimensions and theories by providing taxonomy for categorization of various factors in their respective context. The proposed conceptual model is developed with ten significant factors within four contexts; technological context, organizational context, environmental context and individual context, Technological context consists of relative advantage, complexity, compatibility factors and organizational context has organizational readiness and top management factors. Further, the environmental context comprises competitive pressure and institutional isomorphism. All three contexts depend on individual context because they are the key players and responsible for the success and failure of BI system in organization. On the other hand, organizational size directly affects the BI system adoption in terms of individual, organizational, technological and environmental perspectives. The proposed conceptual model is illustrated in Fig. 4.

\subsection{Rationale behind the Selection of Significant Factors for Model development}

The selection of the most suitable theoretical constructs in our model is decided by their frequency of use and keeping in mind the challenges and opportunities of the T\&A industry of Pakistan. The factor relative advantage refers to the benefits which can be obtained by the adoption of BI systems in several ways such as revenue increment, cost reduction, time reduction and real time access to information [5] that would helpful in better planning of strategies with vigilant decision-making. It benefits to achieve higher employees' satisfaction, higher suppliers/customers satisfaction and efficient industrial procedures. The compatibility factor matters in the context of existing infrastructure that influence the organizational adoption decision for the BI system. if new technology is perceived as compatible with present technologies, value systems and procedures of the strong adopters in context of infrastructure the more likely it will be adopted if not then it can delay the adoption process. Complexity is another major factor that can impede the use and adoption process of BI systems. Further, given potential of BI system can significantly influence an industry's business relationship and competitive position. Therefore, the strong support and active involvement of top management support can improve the better directions and strategic vision by utilizing and adoption of BI system in the T\&A industry. The factor organizational readiness has a great importance as it covers all financial, human, organizational, and technological resources in organizational context. Puklavec et al. [9] stated that BI system is more sensitive in the case of resources availability. The significance of the competitive pressure factor is shown by literature that competitive pressure pushed firms in the high-tech industry like T\& A industry to adopt BI systems more quickly for improving their productivity and efficiency thereby heading to competitive advantage [75]. Moreover, the T\&A industry of Pakistan 


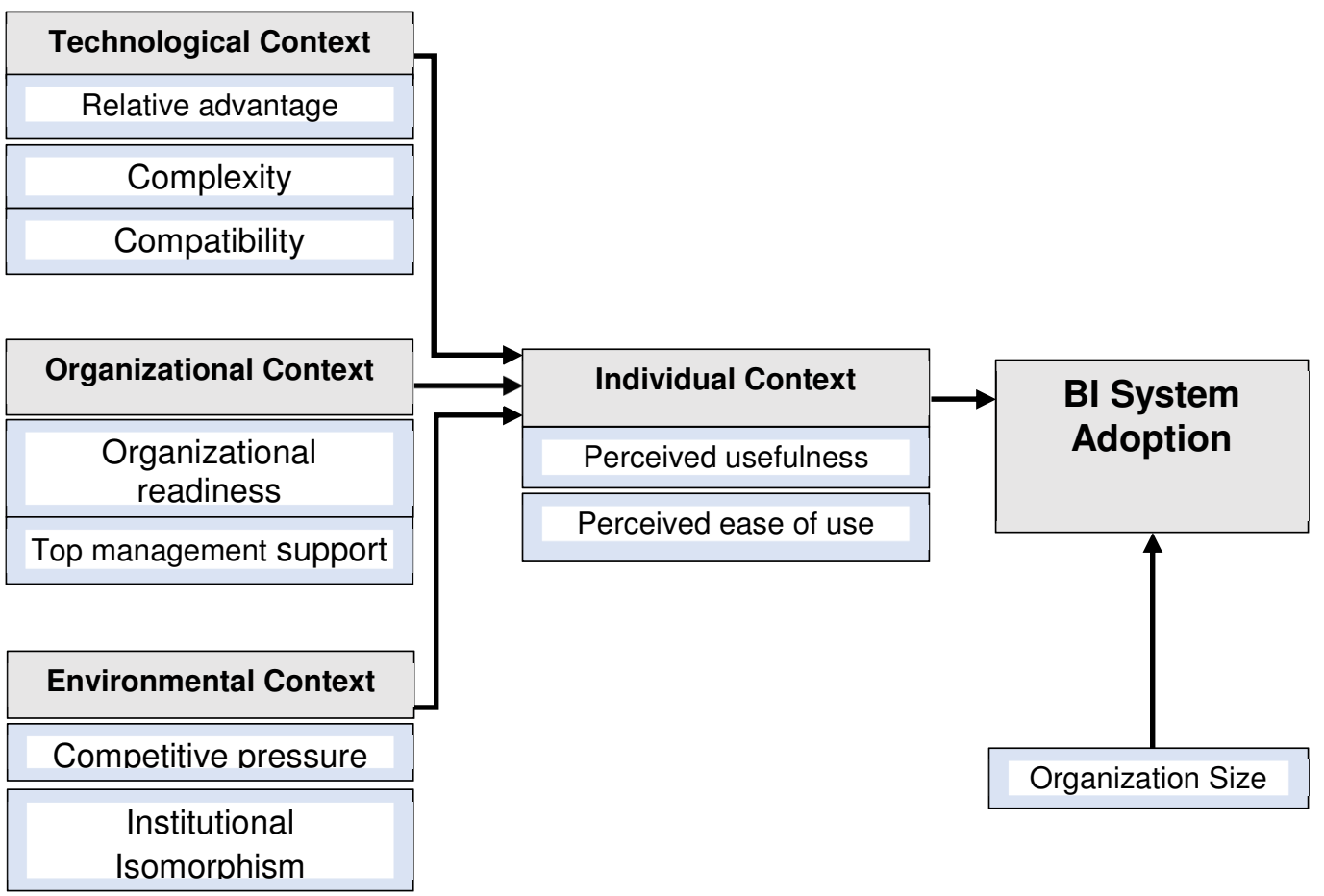

Fig. 4: Conceptual model of BI system adoption for the Textile and Apparel industry

operates in an environment that is influenced by economic, socio- political, and technological pressures which gives rise to institutional isomorphism. Therefore, institutional isomorphism factor is considered significant for the BI system adoption model. Understanding the key role of users' acceptance of the BI system cannot be taken out. Therefore, perceived ease of use and perceived usefulness factors are included in the proposed conceptual model. They can bring potential changes in business operations due to the adoption of BI systems to leverage the true business value for the T\&A industry. Lastly, organization size factor has great significance that directly influence the adoption decision of BI systems especially in developing countries. Organizations, which are large in size are generally considered as rich in terms of resource availability and more prone to invest and adopt costly innovations such as BI systems. The proposed model will guide the decision makers to the successful adoption of BI systems in the T\&A industry of Pakistan. It will be helpful to the industry practitioners to understand how to cater the supplier, retailers' consumers 'needs at limited time and seek the feasible solutions in order to identify cost savings and improve business sustainability in recent competitive textile quota free global trade.

\section{IMPLICATIONS AND CONCLUSION}

This reviewed study has proposed a model with most influential factors for BI system adoption by evaluating the individual, technological, organizational and environmental factors from previous studies. The T\&A industry is facing the challenge of sustainability in competitive environment with international dynamics of business growth, It is also very important to overcome the other challenges such as how to resolve the suppliers, retailers' consumers' issues in short time span and provide the best solutions in order to identify cost savings and improve business sustainability in recent competitive textile quota free global trade. Various factors were identified that influence the opinion of decision makers for the BI system adoption by developing a conceptual model of BI system adoption for the T\&A industry of Pakistan. Total ten significant factors within four contexts; technological context, 
organizational context, environmental context and individual context were selected. Technological context consists of relative advantage, complexity, compatibility factors and organizational context has organizational readiness and top management factors. Further, the environmental context comprises competitive pressure and institutional isomorphism. All three contexts depend on individual context because they are the key players and responsible for the success and failure of BI system in organization. On the other hand, organizational size directly affects the BI system adoption in terms of individual, organizational, technological and environmental perspectives. In addition, this study guides the decision makers to adopt the innovation like BI systems. This review study contributed for both practitioners and academic scholars. For academicians, it provides a valuable synthesis of 10 years studies on BI systems research to present the current scenario of BI system adoption. The research on BI system is still in progress, and this study can guide the scholars, as it presents the potential factors, theories and models used in the BI systems adoption. In addition, the existing honed picture of the existing literature is provided by this review and highlights those areas which were neglected by researchers such as the T\&A industry in the perspective of BI adoption with potential models and theories. Researchers focused more on utilization and validation of existing theories and models such as DOI, UTAUT, TPB, RBV, TOE and TAM for the BI system research domain. They should also consider other theories and models such as decision theory, social cognitive theory and motivation theory in this specific research area that may contribute to the success of BI system adoption before entering into the fourth industrial revolution "Industry 4.0". The findings of this study will guide the industrial and organizational policy makers for improving manufacturing, production and marketing processes and strategies with wise decisionmaking through BI systems adoption.

\subsection{The Study Limitations and Future Research Directions}

This review study has various limitations that are pertinent to be considered. These limitations will provide the future research directions. First, the literature search was focused on factors and theories that were used specifically for the BI system adoption. Researchers may extend this perspective to explore more potential factors that guarantee the success of the BI projects. Secondly, the current study was limited to the BI systems only. Future research would focus on decision making performance with artificial intelligence and machine learning techniques. Thirdly, this study explored the significant factors, comprehensively by examining frameworks, models and theories that were used for the adoption of BI systems in literature. However, it did not identify the relationships among potential factors and their influence on decision-making processes. This area may get the attention of researchers in future and extend the body of knowledge in these directions. Finally, it is recommended that further studies are required to conduct regarding factors identification that might influence the BI system adoption as well as integrating and investigating other theories and models including TAM, TOE, DOI, UTAUT. In addition, it is also confirmed by the results of this study that a more focused research area is the financial and telecommunication industry regarding the adoption of BI systems. Researchers should pay attention further to other industries including the T\&A industry due to its increasing demand. This study guides not only the decision makers to adopt the innovations like BI systems utilizing most significant factors but also suggests scholars to investigate this phenomenon of interest in new dimensions. It is noticeable that this is a significant ongoing research area. The past research is insufficient about the adoption of BI systems especially scarce in the T\&A industry. Consequently, the objective of present study is to pave the way for conducting such more studies. Therefore, the proposed conceptual model of BI system adoption for the T\&A industry is required to be validated empirically with quantitative, qualitative and mix-method research approaches in future.

\section{REFERENCES}

1. Filho W.L., Ellams D., Han S., Tyler D., Boiten V.J., Paço A., Moora H., Balogun A.L., "A review of the socio-economic advantages of textile recycling", Journal of Cleaner Production,. Vol. 
218, pp. 10-20, 2019.

2. Marwat A.M.K., "Textile Policy 2014-19", Ministry of Texile Industry, Government of Pakistan, 2015.

3. Ngai E. W. T., Peng S., Alexander P., Moon K. K. L, "Decision support and intelligent systems in the textile and apparel supply chain: An academic review of research articles", Expert Systems with Applications, Vol. 41, No. 1, pp. 81-91, 2014.

4. Patora-Wysocka Z., Sułkowski L., "Sustainable incremental organizational change-A case of the textile and apparel industry”, Sustinability, Vol.11, No.4, 2019.

5. Ahmad S., Miskon S., Alabdan R., Tlili I., "Towards Sustainable Textile and Apparel Industry: Exploring the Role of Business Intelligence Systems in the Era of Industry 4.0", Sustainability, Vol. 12, No.7, p. 2623, 2020.

6. Abusweilem M. A., Abualoush S., "The impact of knowledge management process and business intelligence on organizational performance," Management Science Letters, Vol. 9, No. 12, pp. 2143-2156, 2019.

7. Jalil N. A., Hwang H. J., "Technological-Centric Business Intelligence : Critical Success Factors", International Journal of Innovation, Creativity and Change, Vol. 5, No. 2, pp. 1499-1516, 2019.

8. Zheng G., "Bringing Business Intelligence to Health Information Technology Curriculum", Journal of Information Systems Education, Vol. 25, No. 4, pp. 317-326, 2014.

9. Puklavec B., Oliveira T., Popovič A., "Understanding the determinants of business intelligence system adoption stages an empirical study of SMEs", Ind. Manag. Data Syst., Vol. 118, No. 1, pp. 236-261., 2018.

10. Pavkov S., Poscic P., Jaksic D., "Business Intelligence Systems Yesterday, Today and Tomorrow - An Overview”, Zbornik Veleučilišta u Rijeci, Vol. 4, No. 1, pp. 97-108, 2016.

11. Combita Niño H. A., Cómbita Niño J. P., Morales Ortega R., "Business intelligence governance framework in a university: Universidad de la costa case study", International Journal of Information Management, Vol. 50, pp. 405-412, 2020.

12. Chen H., Chiang R. H. L., Storey V. C., "Business
Intelligence and Analytics: From Big Data To Big Impact", MIS Quarterly, Vol. 36, No. 4, pp. 1165-1188, 2012.

13. Yeoh W., Popovič A., "Extending the understanding of critical success factors for implementing business intelligence systems," $J$. Assoc. Inf. Sci. Technol., Vol. 67, No. 1, pp. 134147, 2016.

14. Fink L., Yogev N., Even A., "Business intelligence and organizational learning: An empirical investigation of value creation processes," Information and Management, Vol. 54, No.1, pp. 38-56, 2017.

15. Ali M. S., Khan S., Miah S. J., "Understanding towards Interactions between Business Intelligence and SMEs: Learn from Each Other", Information Technology and Management, Vol. 14, No. 2, pp. 151-168, 2017.

16. Ahmad A., Ahmad R., Hashim K. F., "Innovation traits for business intelligence successful deployment", Journal of Theoretical and Applied Information Technology, Vol. 89, pp. 78-89, 2016.

17. Wadho W., Chaudhry A., "Innovation in the Textiles Sector: A Firm-Level Analysis of Technological and Non-Technological Innovation", The Lahore Journal of Economics, Vol. 21, No. SE, pp. 129-166, 2016.

18. Nagy J., Oláh J., Erdei E., Máté D., Popp J., "The role and impact of industry 4.0 and the internet of things on the business strategy of the value chainthe case of hungary," Sustainability, Vol. 10, 2018.

19. Aksoy A., Ozturk N., Sucky E., "A decision support system for demand forecasting in the clothing industry", International Journal of Clothing Science and Technology, Vol. 24, No.4, pp. 221-236, 2012.

20. Ahmad S., Miskon S., The Adoption of Business Intelligence Systems in Textile and Apparel Industry: Case Studies. In Saeed F., Mohammed F., Gazem N. (Eds.) Emerging Trends in Intelligent Computing and Informatics (IRICT), 2019, Advances in Intelligent Systems and Computing, Vol. 1073, Springer, Cham, 2020.

21. Muntean M., "Business intelligence issues for sustainability projects," Sustainability, Vol. 10, 
pp. 1-10, 2018.

22. Veeramisti N., Paz A., Baker J., "A framework for corridor-level traffic safety network screening and its implementation using Business Intelligence", Safety Science, Vol. 121, pp. 100 $110,2020$.

23. Olszak C. M., "Toward Better Understanding and Use of Business Intelligence in Organizations", Information Systems Management, Vol. 33, No. 2, pp. 105-123, 2016.

24. Jin D. H., Kim H. J., "Integrated understanding of big data, big data analysis, and business intelligence: A case study of logistics", Sustainability, 2018.

25. Cheng C., Zhong H., Cao L., "Facilitating speed of internationalization: The roles of business intelligence and organizational agility", Journal of Business Research, Vol. 110, pp. 95-103, 2020.

26. Hatta N. N. M., Miskon S., Ali N.M., Abdullah N.S., Ahmad N., Hashim H., Alias R., Maarof A., "Business intelligence system adoption theories in SMES: A literature review", ARPN Journal of Engineering and Applied Sciences, Vol. 10, No. 23, pp. 18165-18174, 2015

27. Ain N. U., Vaia G., DeLone W. H., Waheed M., "Two decades of research on business intelligence system adoption, utilization and success - A systematic literature review," Decis. Support Syst., Vol. 125, pp. 1-13, 2019.

28. Bertola P., Teunissen J., "Fashion 4.0. Innovating fashion industry through digital transformation", Research Journal of Textile and Apparel, Vol. 22, No. 4, pp. 352-369., 2018.

29. Bach M. P., Čeljo A., Zoroja J., "Technology Acceptance Model for Business Intelligence Systems: Preliminary Research", Procedia Computer Science., Vol. 100, pp. 995-1001, 2016.

30. Jamaludin I., Mansor Z., "Review on Business Intelligence (BI) Success Determinants in Project Implementation", International Journal of Computer Applications, Vol. 33, No. 8, pp. 2427, 2011.

31. Nasab S.S., Selama H., Masrom M., "A delphi study of the important factors for bi system implementation in the public sector organizations", Jurnal Teknologi, Vol. 77, pp. 113-120, 2015.

32. Owusu A., Ghanbari-Baghestan A., Kalantari A., "Investigating the Factors Affecting Business Intelligence Systems Adoption: A Case Study of Private Universities in Malaysia”, International Journal of Technology Diffusion, Vol. 8, No.2, 2017.

33. Jayakrishnan M., Mohamad A. K., Azmi F.R., Abdullah A., "Adoption of business intelligence insights towards inaugurate business performance of Malaysian halal food manufacturing", Management Science Letters, Vol. 8, No.7, pp. 725-736, 2018.

34. Adamala S., Cidrin L., "Key success factors in Business Intelligence", Journal of Intelligent Studies in Business, Vol.1, No.1, 2011.

35. Olszak C. M., Ziemba E., "Critical success factors for implementing business intelligence systems in small and medium enterprises on the example of upper Silesia, Poland", Interdisciplinary Journal of Information, Knowledge and Management, Vol. 7, pp. 130-150, 2012.

36. Grublješič T., Coelho P. S., Jaklič J., "The Shift to Socio-Organizational Drivers of Business Intelligence and Analytics Acceptance," Journal of Organizational and End User Computing, Vol. 31, No.2, 2019.

37. Jaklič J., Grublješič T., Popovič A., "The role of compatibility in predicting business intelligence and analytics use intentions", International Journal of Information Management, Vol. 43, pp. 305-318, December 2018.

38. Grublješič T., Jaklič J., "Business Intelligence Acceptance: The Prominence of Organizational Factors," Information Systems Management, Vol. 32, No. 4, pp. 299-315, 2015.

39. Grublješič T., Jaklič J., "Conceptualization of the business intelligence extended use model," Journal of Computer Information Systems, Vol. 55, No.3, pp. 72-82, 2015.

40. Olexov C., "Business Intelligence Adoption: A Case Study in The Retail Chain," WSEAS Transactions on Business and Economics, Vol. 11, No. 1, pp. 95-106, 2014.

41. Lautenbach P., Johnston K., Adeniran-Ogundipe T., "Factors influencing business intelligence and 
analytics usage extent in South African organisations," South African Journal of Business Management, Vol. 48, No.3, 2017.

42. Dawson L., Van Belle J.-P., "Critical success factors for business intelligence in the South African financial services sector", South African Journal of Business Management, Vol. 15, No. 1, pp. 1-12, 2013.

43. Bijker M., Hart M., "Factors influencing pervasiveness of organisational business intelligence," Proceedings of the Third International Conference on Business Intelligence and Technology, No. c, pp. 21-26, Valencia, Spain, 27 May - 01 June 2013.

44. Owusu A., Agbemabiese G.C., Abdurrahaman D.T., Soladoye B.A., "Determinants of Business Intelligence Systems Adoption in Developing Countries : an Empirical Analysis from Ghanaian Banks", Journal of Internet Banking and Commerce, Vol. 22, No. 8, pp. 1-25, 2017.

45. Kester Q., Preko M., "Business Intelligence Adoption in Developing Economies: A case study of Ghana Business Intelligence Adoption in Developing Economies : A case study of Ghana”, International Journal of Computer Applications, Vol. 127, No.1, pp. 5-11, 2015.

46. Acheampong O., Moyaid S. A., "An integrated model for determining business intelligence systems adoption and post-adoption benefits in banking sector", Journal of Administrative and Business Studies, Vol. 2, No. 2, pp. 84-100, 2016.

47. Stjepić A.M., Sušac L., Vugec D. S., “Technology , Organizational and Environmental Determinants of Business Intelligence Systems Adoption in Croatian SME : A Case Study of Medium- Sized Enterprise", International Journal of Economics and Management Engineering, Vol. 13, No. 5, pp. 725-730, 2019.

48. Popovič A., Puklavec B., Oliveira T., "Justifying business intelligence systems adoption in SMEs: Impact of systems use on firm performance", Industrial Management \& Data Systems, Vol. 119, No. 1, pp. 210-228, 2019.

49. Visinescu L. L., Jones M. C., Sidorova A., "Improving Decision Quality: The Role of Business Intelligence", Journal of Computer Information Systems, Vol. 57, No. 1, pp. 58-66,
2017.

50. Elbashir M. Z., Collier P. A., Sutton S. G., "The role of organizational absorptive capacity in strategic use of business intelligence to support integrated management control systems", The Accounting Review, Vol. 86, No. 1, pp. 155-184, 2011.

51. Ramakrishnan T., Jones M. C., Sidorova A., "Factors influencing business intelligence (BI) data collection strategies: An empirical investigation", Decision Support Systems, Vol. 52, No. 2, pp. 486-496, 2012.

52. Sujitparapitaya S., Shirani A., Roldan M., "Business Intelligence Adoption in Academic Administration: an Empirical Investigation", Issues in Information Systems, Vol. 3, No. 2, pp. 112-122, 2012.

53. Chaveesuk S., Horkondee S., "An integrated model of business intelligence adoption in Thailand logistics service firms", Proceedings of the $7^{\text {th }}$ International Conference on Information Technology and Electrical Engineering, Chiag Mai, Thailand, pp. 604-608, 29-30 October 2015.

54. Bhatiasevi V., Naglis M., "Elucidating the determinants of business intelligence adoption and organizational performance", Information Development, Vol. 36, No. 1, pp. 78-96, 2020.

55. Foshay N., Kuziemsky C., "Towards an implementation framework for business intelligence in healthcare", International Journal of Information Management, Vol. 34, No. 1, pp. 20-27, 2014.

56. Rouhani S., Ashrafi A., Ravasan A. Z., Afshari S., "Business Intelligence Systems Adoption Model: An Empirical Investigation", Journal of Organizational and End User Computing, Vol. 30, No. 2, pp. 43-70, 2018.

57. Pool J.K., Jamkhaneh H.B., Tabaeeian R.A., Tavakoli R.A., Shahin A., "The effect of business intelligence adoption on agile supply chain performance", International Journal of Productivity and Quality Management, Vol. 23, No. 3, pp. 289-306, 2018.

58. Högskolan F. i Halmstad. and C. N. Niamba, "Identifying key effective factors on the implementation process of business intelligence in the banking industry of Iran", Journal of 
Intelligent Studies in Business, Vol. 6, No. 1, pp. 17-33, 2016.

59. Wang H. C., "Distinguishing the adoption of business intelligence systems from their implementation: The role of managers personality profiles", Behavior \& Information Technology, Vol. 33, No. 10, pp. 1082-1092, 2014.

60. Hou C. K., "Investigating factors influencing the adoption of business intelligence systems: An empirical examination of two competing models", International Journal of Technology, Policy and Management, Vol. 13, No. 4, pp. 328-353, 2013.

61. Hou C. K., "Exploring the user acceptance of business intelligence systems in Taiwan's electronics industry: applying the UTAUT model", International Journal of Internet and Enterprise Management, Vol. 8, No. 3, p. 195, 2014.

62. Yoon E., Ghosh B., Jeong B. K., "User acceptance of business intelligence (BI) application: Technology, individual difference, social influence, and situational constraints," Proceedings of the Hawaii International Conference on System Sciences, pp. 3758-3766, 2014.

63. Puklavec B., Oliveira T., Popovic A., "Unpacking Business Intelligence Systems Adoption Determinants: An Exploratory Study of Small and Medium Enterprises", Economic and Business Review, Vol. 16, No. 2, pp. 185-213, 2014.

64. Mathew S. K., "Adoption of business intelligence systems in Indian fashion retail", International Journal of Business Information Systems, Vol. 9, No. 3, pp. 261-277, 2012.

65. Audzeyeva A., Hudson R., "How to get the most from a business intelligence application during the post implementation phase? Deep structure transformation at a U.K. retail bank", European Journal of Information Systems, Vol. 25, No. 1, pp. 29-46, 2016.

66. García J. M. V., Pinzón B. H. D., “Key success factors to business intelligence solution implementation", Journal of Intelligent Studies in Business, Vol. 7, No. 1, pp. 48-69, 2017.

67. Kohnke O., Wolf T. R., Mueller K., "Managing user acceptance: An empirical investigation in the context of business intelligence standard software", International Journal of Information Systems and Change Management, Vol. 5, No.4, pp. 269-290, 2011.

68. Brockmann T., Stieglitz S., Kmieciak J., Diederich S., "User acceptance of mobile business intelligence services", Proceedings of the 15th International Conference on NetworkBased Information Systems (NBIS), Melbourne, Australia, pp. 861-866, 26-28 September 2012.

69. Moreno V., Elias Lobo Vieira da Silva F., Ferreira R., Filardi F., "Complementarity as a Driver of Value in Business Intelligence and Analytics Adoption Processes", Revista Ibero Americana de Estratégia, Vol. 18, No.1, pp. 57$70,2018$.

70. Weber R., "Evaluating and developing theories in the information systems discipline", Journal of the Association for Information Systems, Vol. 13, No. 1, 2012.

71. Nord J. H., Koohang A., Paliszkiewicz J., "The Internet of Things: Review and Theoretical Framework", Expert Systems with Applications, Vo. 133, pp. 97-108, November 2019.

72. Venable J., Pries-Heje J., Baskerville R., "FEDS: A Framework for Evaluation in Design Science Research", European Journal of Information Systems, Vol. 25, pp. 77-89, 2016.

73. Alter S., "Nothing is more practical than a good conceptual artifact... which may be a theory, framework, model, metaphor, paradigm or perhaps some other abstraction", Information Systems Journal, Vol. 27, pp. 671-93, 2017.

74. Carvalho S., Portela F., Santos M.F., Abelha A., Machado J., "Step towards of a Homemade Business Intelligence Solution - A Case Study in Textile Industry", In Rocha A., Correia A., Costanzo S., Reis L. (Eds.), Advances in Intelligent Systems and Computing, Vol. 353, Springer, pp. 361-370, 2015.

75. Istrat V., Lalić N., "Association rules as a decision making model in the textile industry", Fibers and Textiles in Eastern Europe, Vol. 25, No. 4, pp. 814, 2017. 